\title{
Risk and Return Analysis of Mutual Fund Industry in India
}

\section{Bilal Ahmad Pandow ${ }^{1}$ Khurshid Ahmad Butt ${ }^{2}$}

'Senior Lecturer, Middle East College, Oman

¿Dean, Faculty of Commerce \& Management Studies, University of Kashmir

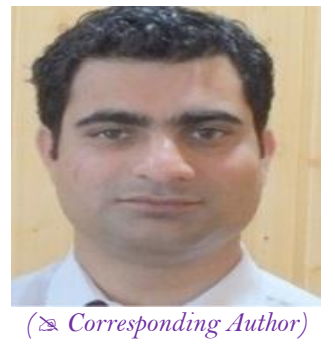

(A) Check for updates

\begin{abstract}
The mutual funds is one of the important classes of financial intermediaries enabling tens of thousands small and large savers across India to participate in and get the benefits of the capital market. The involvement of mutual funds in the transformation of India's economy makes it all the more important to review their services for their role in mobilization and allocation of funds in the markets. The mutual funds have a lot of potential to grow but to capitalize the potential fully, however, the need is to create and market innovative products and frame distinct marketing strategies. Moreover, the equity culture has not yet developed fully in India as such, investor education would be equally important for greater penetration of mutual funds. As such mutual funds are expected to perform better than the market, therefore calls for a continuous evaluation of the performance of funds. In an academic perspective, the goal of identifying superior fund managers is of great interest due to the challenges it provides to the efficient market hypothesis. The present study looks into the risk and return analysis of the select mutual funds in India.
\end{abstract}

Keywords: Mutual funds, Risk, Return, Investors

\section{Introduction}

Since its inception, the mutual fund industry has come a long way in India, the remarkable growth in the Indian mutual fund industry can be ascribed to multiple factors like, rise in savings of household, all-inclusive regulatory framework, and satisfactory tax policies, start of several new products, investor educational campaigns and the role of brokers. More pleasing aspect of the Indian fund market is that it has graduated from offering plain vanilla equity and debt funds, to an array of diverse products such as capital protection oriented funds, exchange traded funds, gold funds, and even the native funds. Although, the fund industry in India has achieved many milestones yet the potential that it enjoys remains unrealized. For example, assets under management as a percentage of GDP for India is about 5 to 6 percent, significantly lower than some other emerging economies like Brazil and South Africa having 40 percent and 33 percent respectively. The other fact is that the fund industry in the country is yet to spread its reach beyond Tier-I cities which accounts for around 74 percent of the fund folios as on September 2013. There is also an interplay of cultural and behavioral factors which prevents savings from being streamlined into mutual funds. Therefore, if these and other challenges are properly addressed, the fund industry in the country will likely achieve newer heights.

Treynor (1965) used the characteristic line for relating expected rate of return of a fund to the rate of return (ROR) of a suitable market average. The researcher even coined the fund performance measure taking investment risk into account. Also, to deal with a portfolio, portfolio possibility line was used to relate expected return to the portfolio owner's risk preference. A composite portfolio evaluation technique regarding the risk-adjusted returns was used by Jensen (1968). The researcher evaluated the ability of 115 fund managers in selecting securities during the period 1945-66. Analysis of net returns indicated that, 39 funds had above average returns, while 76 funds yielded abnormally poor returns. Using the gross returns, 48 funds showed above average results and 67 funds below average results. On the basis of the study Jensen concluded that there was very little evidence that funds were able to perform significantly better than expected as fund managers were not able to forecast securities price movements.

The most prominent study by Sharpe (1966) developed a composite measure of return and risk. The researcher evaluated 34 open-end mutual funds for the period 1944-63. The study revealed that the reward to variability ratio for each scheme was significantly less than DJIA and ranged from 0.43 to 0.78 . Also, it reveals that expense ratio was inversely related with the fund performance, as correlation coefficient was 0.0505 . The results showed that notable performance was linked with the low expense ratio and not with the size. Also, the sample schemes showed consistency in risk measure. 
The performance of 86 funds with random portfolios was compared by Irwin et al. (1970). The study has concluded that, mutual funds performed badly in terms of total risk. Funds with higher turnover outperformed the market. The size of the fund did not have any impact on their performance.

The methods to distinguish observed return due to the ability to pick up the best securities at a given level of risk from that of predictions of price movements in the market was developed by Fama (1972). The researcher, introduced a multi-period model allowing evaluation on a period-by-period and on a cumulative basis. The researcher explained that the return on a portfolio constitutes return for security selection and return for bearing risk. His contributions combined the concepts from modern theories of portfolio selection and capital market equilibrium with more traditional concepts of good portfolio management. The investment performance of 40 funds was analyzed by Klemkosky (1973) based on quarterly returns during the period 1966-71. The researcher acknowledged that, the biases in Sharpe, Treynor, and Jensen's measures, could be disinterested by using mean absolute deviation and semi-standard deviation as risk surrogates associated to the composite measures resulting from the capital asset pricing model. Khare (2007) opined that investors could purchase stocks or bonds with much lower trading costs through mutual funds and enjoy the advantages of diversification and lower risk. The researcher identified that, with a higher savings rate of 23 percent, channeling savings into mutual funds sector has been growing rapidly as retail investors were gradually keeping out of the primary and secondary market.

Similarly, the results and conclusions made by Ippolito (1989) were relevant and consistent with the theory of efficiency of the informed investors. The researcher estimated that risk-adjusted return for the mutual fund industry was more than zero and identified that fund performance was not related to expenses and turnover as predicted by efficiency arguments. Also, Fortin and Michelson (1995) studied 1326 load funds and 1161 no-load funds and has found that, no-load funds had lower expense ratio and were suitable for six years, while the loadfunds had higher expense ratio and so had fifteen years of average holding period. No-load funds offered superior results in nineteen out of twenty-four schemes. Based on these findings, the researcher has concluded that the mutual fund investor had to remain invested in a particular fund for very long periods to recover the initial frontend charge and achieve investment results similar to that of no-load funds.

An analysis of the implications of conditioning information variables on a sample of Portuguese stock funds was attempted by Cortez and Silva (2002). The researchers identified that unconditional Jensen's alpha ensured superior performance till incorporation of public information variables. Alpha was not statistically different from zero while beta was related to public information variables.

While, Rohleder et al. (2014) used a matched sample of 2,588 actively managed U.S. domestic equity funds from the CRSP mutual fund database and the SEC's N-SAR filings, they detect cross-sectional differences in the response of funds to flow risk. The researcher also found that the funds using complex instruments, such as derivatives and leverage strategies, have higher performance than non-using funds. The study also showed that this outperformance is not a result of employing complex instruments for stock-picking or market-timing activities. Rather, user funds are able to mitigate parts of the adverse relation between investor flows and risk-adjusted performance with complex instruments.

Choi et al. (2017) used the on security holdings for 10,771 institutional investors from 72 countries, and tested whether concentrated investment strategies result in excess risk-adjusted returns. And the results suggest, in contrast to traditional asset pricing theory and in support of information advantage theory, that concentrated investment strategies in international markets can be optimal. Soni (2017) in the study analyzed the returns of various asset classes and correlate these with their risk characteristics in order to verify whether there is always a positive relation between risk and return across all asset classes and to find out the portfolio mix of the various asset classes corresponding to the desired return and risk.

Kholkin and Haug (2016) applied dataset consists of 74 Norwegian open-end equity funds with monthly observations. On average, they found quite low significance of all used models, compared to basic Capital Asset Pricing Model and excluding the Carhart (1997) model. Also, they found that funds with a top high idiosyncratic volatility have lower returns than other funds. More ever, they also found that funds with close to mean idiosyncratic volatility have the highest returns. Grinblatt et al. (2016) reveal stark differences between the investment philosophy and skill of hedge funds and mutual funds. Hedge funds tend to buy stocks with low past returns, while mutual funds tend to be trend followers. Jagric et al. (2015) studied the mutual fund industry and applies various tests to evaluate the performance capacity of mutual funds. They found that the rankings obtained by performing both the Sharpe and Treynor rules to be almost the same, implying that funds are well diversified. The rankings reveal that all analyzed funds outperformed the market on a risk-adjusted basis.

Bali et al. (2014) estimated hedge fund and mutual fund exposure to measures of macroeconomic risk that are interpreted as measures of economic uncertainty. They found that the resulting uncertainty betas explain a significant proportion of the cross-sectional dispersion in hedge fund returns. However, the same is not true for mutual funds, for which there is no significant relationship. After controlling for a large set of fund characteristics and risk factors, the positive relation between uncertainty betas and future hedge fund returns remains economically and statistically significant. Hence, they argue that macroeconomic risk is a powerful determinant of cross-sectional differences in hedge fund returns. Amihud and Goyenko (2013) proposed that fund performance is predicted by its $\mathrm{R}^{2}$, obtained by regressing its return on the Fama-French-Carhart four benchmark portfolios. Lower $\mathrm{R}^{2}$, or higher idiosyncratic risk relative to total risk, measures selectivity or active management. We show that lagged $\mathrm{R}^{2}$ has significant negative predictive coefficient in predicting alpha or Information Ratio.

A strong link between the dispersion in beliefs among mutual fund managers was established by Jiang and Sun (2014) and the study also revealed through their active holdings, and future stock returns. The effect of dispersion on returns is particularly pronounced among stocks with high information asymmetry, moreover, the lower returns on stocks with low dispersion concentrate on those with binding short-sale constraints. The results are consistent with a subgroup of informed managers driving up the dispersion in active holdings when they place large bets after receiving positive information signals unobserved by their peers; conversely, binding short-sale constraints prevent them from fully using their negative private information, leading to low dispersion in active holdings. 


\subsection{Analysis}

As of 2011 the mutual fund industry in the country is dominated by the private sector funds. Though India has achieved sufficient growth in the number of fund houses over a period of time but the mutual funds market is highly concentrated. Out of the 44 AMCs operating in India, approximately 80 percent, of the AUM is concentrated with 11 leading players in the market. These funds includes HDFC Mutual Fund (13 percent), Reliance Mutual Fund (12 percent), ICICI Prudential (10 percent), UTI (9 percent), Birla Sun Life (9 percent), SBI Mutual Funds(7 percent), Franklin Templeton ( 5 percent), IDFC Mutual Fund (5 percent), Kotak Mahindra Mutual Fund ( 4 percent), DSP Black Rock Mutual Fund ( 4 percent) and Axis Mutual Fund (2 percent). While, the remaining 33 mutual funds account for 20 percent of AUMs as on 2013. Also, the remaining 33 mutual funds account for 20 percent of AUMs as on 2013. This is indicative of the fact that the market is highly concentrated. Based on these findings it can be safely observed that for the normal growth of the industry, the need of the hour is to see the disbursement of the business across the fund houses.

Mutual Funds are primarily vehicles for channeling savings of small investors into financial markets who otherwise on their own find difficult to plan and manage their investments in today's complex, mature and information driven financial markets. Routing of investments through mutual funds is generally guided by the advantages of professional management, diversification, and economies of scale. As such mutual funds are expected to perform better than the market, therefore calls for a continuous evaluation of the performance of funds. The assessment of fund manager's performance is important for two reasons: one it enables investors to allocate investible funds into different funds efficiently second it influences the compensation of fund managers. From an academic perspective, the goal of identifying superior fund managers is interesting because it challenges the efficient market hypothesis.

\subsection{Objectives of the Study}

The study is aimed to achieve the following specific objectives:

1. To analyze the growth and development of Indian mutual fund industry and to identify the challenges confronting by the industry.

2. To analyze risk and return of select mutual fund in India.

\subsection{Hypotheses} study:

As mentioned in the above objectives, the following hypotheses are laid in order to provide a direction to the

H1: There is a significant difference between fund returns and risk free return

$\mathrm{H} 2$ : There is a significant difference between fund returns and market return

H3: There is no difference between risk-adjusted fund return and market return

H4: There is a significant difference in the riskiness of the funds and the market portfolio

\section{Data and Methodology}

To test the hypothesis, the data set used was collected from the database of Association of Mutual Funds of India (AMFI) for Net Asset Value (NAV). And for the National Stock Exchange (NSE) for S\&P CNX Nifty and the Reserve Bank of India for the risk free rate. The fund returns were calculated on the basis of daily NAVs rather than monthly NAVs for the reason that above mentioned research has revealed that the high frequency data such as daily NAVs have more revealing power than less frequency data.

Further, the daily returns so obtained were annualized using geometric averaging to obtain average annual fund return. The yields on 91-day treasury bills issued by central bank of India: Reserve Bank of India (RBI) have been used as a proxy for risk-free return. Besides, S\&P CNX Nifty is used as surrogate for the market portfolio/return as well as for bench-mark variability.

In the present study we have used sharp Ratio and Treynor ratio to measures returns per unit of risk. Also, the two ratios gives you the two dimensional picture of the performance of the fund manager like: in Sharpe's ratio total risk (Systematic risk and unsystematic risk) is taken into account whereas in case of the Treynor ratio the researcher has to take systematic risk in to account only.

\subsection{Scope and Reference Period of the Study}

The mutual fund industry in India consists of public, private and foreign funds. All the three sectors were taken for the study so as to compare the performance on the basis of sponsorship of funds. However, for the study we have chosen active funds belongings to growth, income, balanced and tax-saving schemes were selected for the present study.

For this study we have taken into account the period of study is five years from 2007 to 2011 . And the rationale for selecting the study period of 5-years due to two reasons: Firstly, during this period, the stock market witnessed high volatility and was of great interest for the study, as such selected to find-out whether the funds have been able to surpass the market performance even under down-market conditions. Also, the five years were long enough to capture different market phases and to draw meaningful conclusions.

\subsection{Sample Design}

Since large number of schemes were in existence during the period of the study, as such due to time and other constraints, it was difficult and not possible to study all the schemes. It is in view of this fact, an adequate and representative sample was drawn from the universe using convenience sampling method. Initially, the study viewed 76 schemes out of 587 schemes existing as on $1^{\text {st }}$ April 2007, however, the availability of consistent data during the study period (2007 to 2011) was available for 40 schemes only, as such the final sample size for the present study was reduced to 40 schemes, accounting for around 70 percent of the total schemes. These schemes belonged to 19 fund houses consisting of all the three sectors viz. public sector, private sector foreign funds, of the 
total sample size of 40 schemes, 33 schemes belonged to the private sector and 7 to the public sector including UTI. Further, 37 schemes are open-ended and 3 schemes are close-ended in nature. Aim wise, the sample consisted of 28 growth schemes, 3 income schemes, 3 balanced funds and 6 tax-saving schemes.

\subsection{Models Used}

Initially we have assessed the overall performance of the sample funds by analyzing their excess return, $\left(\mathrm{R}_{\mathrm{p}}-\mathrm{R}_{\mathrm{f}}\right)$, abnormal excess return, $\left(\mathrm{R}_{\mathrm{p}}-\mathrm{R}_{\mathrm{m}}\right)$, and riskiness of funds vis-à-vis. market portfolio. Then the poor or superior performance was decomposed by assessing whether the fund performance is due to the stock selectivity skills or market timing abilities of fund managers. The daily returns for each of the sample schemes and the market portfolio have been calculated after making proper adjustments for the dividend, if any, paid by the schemes, as follows:

Where:

$$
\text { Fund Return (Rpt) }=\frac{\mathrm{NAV}_{\mathrm{t}}-\mathrm{NAV}_{\mathrm{t}-1}}{\mathrm{NAV}_{\mathrm{t}-1}}
$$

$\mathrm{R}_{\mathrm{pt}}=$ Return of a scheme at the end of day $\mathrm{t}$

$\mathrm{NAV}_{\mathrm{t}}=$ Net assets value of the scheme at the end of day ' $\mathrm{t}$ '

$\mathrm{NAV}_{\mathrm{t}-1}=$ Net assets value of the scheme at the beginning of day ' $\mathrm{y}$ '

Similarly the daily returns for the market Index i.e. for S\&P CNX Nifty have been calculated using the following formula:

Where:

$$
\text { Market Index Return }(\mathrm{Rmt})=\frac{\mathrm{MI}_{\mathrm{t}}-\mathrm{MI}_{\mathrm{t}-1}}{\mathrm{~S} \& P C N X N \text { ftyt }_{\mathrm{t}-1}}
$$

$\mathrm{R}_{\mathrm{mt}}=$ Return of the market Index for the day ' $\mathrm{t}$ '

$\mathrm{MI}_{\mathrm{t}}=$ Market value of the market index i.e. S\&P Nifty at the end of day ' $\mathrm{t}$ '

$\mathrm{MI}_{\mathrm{t}-1}=$ Market value of the Market Index i.e. $\mathrm{S} \& \mathrm{P}$ Nifty in the beginning of day ' $\mathrm{t}$ '

The daily returns are then annualized to obtain mean annual daily returns of each sample scheme and the market Index as follows:

Mean Annual Daily Portfolio Return $\left(\mathrm{R}_{\mathrm{pt}} \mathrm{-a}\right)=\left(\mathrm{R}_{\mathrm{p} 1}+\mathrm{R}_{\mathrm{p} 2}+\mathrm{R}_{\mathrm{p} 3}+\ldots \ldots \ldots \mathrm{R}_{\mathrm{pn}}\right) / \mathrm{N}$

Mean Annual Daily Market Return $\left(\mathrm{R}_{\mathrm{mt}}-\mathrm{a}\right)=\left(\mathrm{R}_{\mathrm{m} 1}+\mathrm{R}_{\mathrm{m} 2}+\mathrm{R}_{\mathrm{m} 3} \ldots \ldots . \mathrm{R}_{\mathrm{mn}}\right) / \mathrm{N}$

\subsubsection{Excess Return}

On the basis of mean annual daily return, excess return and abnormal excess return the overall performance of the sample schemes was assessed, which were defined as under:

Where:

Excess Fund Return $\left(\mathrm{E}_{\mathrm{RP}}\right)=\left(\mathrm{R}_{\mathrm{pt}-\mathrm{a}}-\mathrm{R}_{\mathrm{ft}-\mathrm{a}}\right)$

$\mathrm{E}_{\mathrm{RP}}=$ Excess mean annual daily fund return

$\mathrm{R}_{\mathrm{Pt}-\mathrm{a}}=$ Mean annual daily return of the scheme for five years

$\mathrm{R}_{\mathrm{ft}-\mathrm{a}}=$ Mean annual daily return of the 91 , days treasury bills for five year study period

\subsubsection{Risk-Adjusted Return}

Since the sample schemes differs in risk with the market index, and also with each other, therefore excess abnormal fund return does not reveal a true picture of the funds' performance. To get a true picture, it becomes necessary to take into account variability or volatility of the returns of the scheme to calculate the risk-adjusted excess return. For this purpose, we have used sharp Ratio and Treynor ratio which measures the unit of reward received per unit of risk. The difference between the two ratios is that Sharpe's ratio takes into account total risk (Systematic risk and unsystematic risk) whereas Treynor ratio considers systematic risk only.

The formulations of the two ratios are as follows:

$$
\begin{aligned}
& \text { Sharpe Ratio }(S)=R_{p t}-R_{f t} / \sigma t \\
& \text { Treynor Ratio }(T)=R_{p t}-R_{f t} / \beta t
\end{aligned}
$$

$\mathrm{S}=$ Sharpe ratio

$\mathrm{T}=$ Treynor ratio

$\mathrm{R}_{\mathrm{pt}}=$ Mean annual daily return of the scheme

$\mathrm{R}_{\mathrm{ft}}=$ Mean annual daily risk- free rate of 91- day Treasury

$\delta \mathrm{t}=$ Standard deviation of mean annual daily returns of the scheme

$\beta \mathrm{t}=$ Beta of mean annual daily returns of the scheme

However, instead of using the risk-free return rate, we have used market return in order to calculate the proxy for the risk adjusted return over the market benchmark rate.

\subsection{Hypotheses Testing}

To provide a direction to the study, hypotheses were set which were tested by using relevant statistical tools. To assess the riskiness of the sample funds and bench mark market index, standard deviation and Beta co-efficient has been used. Standard deviation has been used to assess the total risk while as Beta co-efficient has been used to determine the component of systematic risk.

\section{Results}

Superior financial performance of fund managers has been the single most important factor that has the bearing on investors' interest and growth of mutual fund industry. Therefore, the ultimate goal of fund managers is to deliver superior value to the fund investors in the form of returns at minimum risk. The performance of mutual funds is generally defined in terms of returns, risk adjusted returns or benchmark comparisons. Accordingly to 
comment on the overall performance of sample schemes for the present study, we have used the following measures:

- $\quad$ Excess Return=Fund Return $\left(\mathrm{R}_{\mathrm{pt}}\right)$ - Risk-free Return $\left(\mathrm{R}_{\mathrm{ft}}\right)$

- Abnormal Excess Return = mean Fund return (Rpt) - Rp - Mean market Return (Rmt)

- Risk differential between Fund and Benchmark using co-variance and Standard Deviation i.e. Beta Risk adjusted return using CAPM 
Table-1.1. Mean Daily Annual Excess Return \& Mean Daily Annual Excess Abnormal Return of Sample Funds for Five Year Period (2007-2011).

\begin{tabular}{|c|c|c|c|c|c|}
\hline Schemes & $\begin{array}{l}\text { Mean Daily Annual } \\
\text { Fund Return (Rpt) }\end{array}$ & $\begin{array}{l}\text { Mean Daily Annual } \\
\text { Market Return (Rmt) }\end{array}$ & $\begin{array}{l}\text { Risk Free Return } \\
\text { (Rft) }\end{array}$ & $\begin{array}{l}\text { Mean Daily Excess } \\
\text { Return (Rpt-Rft) }\end{array}$ & $\begin{array}{l}\text { Mean Daily Annual Excess } \\
\text { Abnormal Return } \\
\text { (Rpt-Rmt) }\end{array}$ \\
\hline Baroda Pioneer ELSS & 0.17582 & 0.10037 & 0.07527 & 0.10055 & 0.07545 \\
\hline Baroda Pioneer Growth & 0.23406 & 0.10037 & 0.07527 & 0.15879 & 0.13369 \\
\hline Birla Sun Life Frontline Equity & 0.24004 & 0.10037 & 0.07527 & 0.16477 & 0.13967 \\
\hline Birla Sun Life Top 100 Fund - Growth & 0.19947 & 0.10037 & 0.07527 & 0.12421 & 0.09911 \\
\hline Fidelity Equity Fund & 0.21251 & 0.10037 & 0.07527 & 0.13724 & 0.11214 \\
\hline Franklin India Bluechip Fund & 0.24666 & 0.10037 & 0.07527 & 0.17139 & 0.14629 \\
\hline HDFC Equity Fund & 0.29875 & 0.10037 & 0.07527 & 0.22349 & 0.19839 \\
\hline HDFC Tax Saver Fund & 0.25853 & 0.10037 & 0.07527 & 0.18326 & 0.15816 \\
\hline HSBC Cash Fund & 0.06216 & 0.10037 & 0.07527 & -0.01311 & -0.03821 \\
\hline HSBC Equity Fund & 0.17761 & 0.10037 & 0.07527 & 0.10234 & 0.07724 \\
\hline ICICI Pru Tax Plan & 0.27500 & 0.10037 & 0.07527 & 0.19974 & 0.17464 \\
\hline ICICI Prudential Discovery Fund - Growth & 0.34368 & 0.10037 & 0.07527 & 0.26841 & 0.24331 \\
\hline ING Balanced Fund (D) & 0.15392 & 0.10037 & 0.07527 & 0.07866 & 0.05356 \\
\hline ING Core Equity Fund -Growth & 0.17961 & 0.10037 & 0.07527 & 0.10435 & 0.07925 \\
\hline ING Tax Savings Fund & 0.17483 & 0.10037 & 0.07527 & 0.09957 & 0.07447 \\
\hline JM Balanced Fund - (D) & 0.05516 & 0.10037 & 0.07527 & -0.02010 & -0.04520 \\
\hline Kotak 50 Growth & 0.18094 & 0.10037 & 0.07527 & 0.10567 & 0.08058 \\
\hline Kotak Equity Arbitrage Growth & 0.07717 & 0.10037 & 0.07527 & 0.00190 & -0.02320 \\
\hline L\&T Growth Fund & 0.19081 & 0.10037 & 0.07527 & 0.11554 & 0.09044 \\
\hline LIC Nomura Mf Equity Fund & 0.14311 & 0.10037 & 0.07527 & 0.06785 & 0.04275 \\
\hline LIC Nomura Mf India Vision Fund (D) & 0.12295 & 0.10037 & 0.07527 & 0.04769 & 0.02259 \\
\hline Morgan Stanley Growth Fund & 0.17809 & 0.10037 & 0.07527 & 0.10283 & 0.07773 \\
\hline Principal Index Fund & 0.19014 & 0.10037 & 0.07527 & 0.11487 & 0.08977 \\
\hline Principal Personal Tax Saver Fund & 0.08750 & 0.10037 & 0.07527 & 0.01223 & -0.01287 \\
\hline Quantum Liquid Fund - Growth & 0.07415 & 0.10037 & 0.07527 & -0.00112 & -0.02621 \\
\hline Quantum Long-Term Equity Fund & 0.22769 & 0.10037 & 0.07527 & 0.10283 & 0.12732 \\
\hline Reliance Growth Fund & 0.28849 & 0.10037 & 0.07527 & 0.21323 & 0.18813 \\
\hline Reliance Regular Savings Fund & 0.27089 & 0.10037 & 0.07527 & 0.19562 & 0.17052 \\
\hline Sahara Growth Fund & 0.18653 & 0.10037 & 0.07527 & 0.11127 & 0.08617 \\
\hline Sahara Growth Fund - Div & -0.00377 & 0.10037 & 0.07527 & -0.07904 & -0.10414 \\
\hline SBI Arbitrage Opportunities Fund & 0.07508 & 0.10037 & 0.07527 & -0.00019 & -0.02529 \\
\hline $\begin{array}{l}\text { SBI Magnum NRI Investment Fund-Flexi Asset (D) } \\
\text { Balanced }\end{array}$ & 0.14899 & 0.10037 & 0.07527 & 0.07372 & 0.04863 \\
\hline SBI One India Fund & 0.10606 & 0.10037 & 0.07527 & 0.03079 & 0.00569 \\
\hline Sundaram Growth Fund & 0.22263 & 0.10037 & 0.07527 & 0.14736 & 0.12226 \\
\hline Sundaram Select Focus & 0.21523 & 0.10037 & 0.07527 & 0.13997 & 0.11487 \\
\hline Tata Pure Equity Fund & 0.23666 & 0.10037 & 0.07527 & 0.16139 & 0.13629 \\
\hline Tata Tax Advantage Fund & 0.24386 & 0.10037 & 0.07527 & 0.16859 & 0.14349 \\
\hline Templeton India TMA & 0.07187 & 0.10037 & 0.07527 & -0.00340 & -0.02850 \\
\hline
\end{tabular}


Journal of Banking and Financial Dynamics, 2017, 1: 54-65

\begin{tabular}{l|l|l|l|l|l}
\hline UTI - Growth Retail & 0.20554 & 0.10037 & 0.07527 & 0.13027 & 0.10517 \\
\hline UTI - Opportunities Fund & 0.32868 & 0.10037 & 0.07527 & 0.25341 \\
\hline Mean Return & $\mathbf{0 . 1 8 3 9 3}$ & $\mathbf{0 . 1 0 0 3 7}$ & $\mathbf{0 . 0 7 5 2 7}$ & $\mathbf{0 . 1 0 7 4 2}$ \\
\hline
\end{tabular}

Mean Return

0.10037

$\mathbf{0 . 0 8 3 5 6}$

Rpt: Mean Daily Annual Fund Return

- Rmt: Mean Daily Annual Market Return

Source: AMC reports, NSE histo

NSE his orical data and RBI reports 
Table 1.1 given above presents the overall performance of sample funds. Perusal of the data contained in the above mentioned table reveals that all the 40 sample fund schemes except Sahara Growth Fund have succeeded to score positive returns during the period under study (2007-2011) with an average return of 18.39 percent. The return of the sample schemes during the reference period have ranged between -0.37 percent to 34.36 percent. The Sahara Growth Fund has been the only fund which has reported negative returns of 0.37 percent during the period. 20 funds namely Baroda Pioneer Growth, Birla Sun Life Frontline Equity, Birla Sun Life Top 100 Fund-Growth, Fidelity Equity Fund, Franklin India Bluechip Fund, HDFC Equity Fund, HDFC Tax Saver Fund, ICICI PRU Tax Plan, ICICI Prudential Discovery Fund-Growth, L\&T Growth Fund, Principal Index Fund, Quantum LongTerm Equity Fund, Reliance Growth Fund, Reliance Regular Savings Fund, Sundaram Growth Fund, Sundaram Select Focus, Tata Pure Equity Fund, Tata Tax Advantage Fund, UTI-Growth Retail and UTI-Opportunities Fund have earned more than the average return of 18.39 percent.

It can also be seen from the data contained in the above referred table that the mean return of 18.39 percent of sample fund schemes during the period has been significantly greater than the mean market return of 10.03 percent. Out of the 40 sample schemes, mean return of 32 i.e. 80 percent of the schemes have been greater than the mean market return of 10.03 percent. However, eight sample schemes or 20 percent of the sample size namely HSBC Cash Fund, JM Balanced Fund-(D), Kotak Equity Arbitrage Growth, Principal Personal Tax Saver Fund, Quantum Liquid Fund-Growth, Sahara Growth Fund-Div, SBI Arbitrage Opportunities Fund, and Templeton India TMA have reported less than the mean market return. While comparing with the risk-free return, it can be observed that the mean returns of 6 funds representing 15 percent of the total sample size namely HSBC Cash Fund, JM Balanced Fund-(D), Quantum Liquid Fund-Growth, Sahara Growth Fund-Div, SBI Arbitrage Opportunities Fund and Templeton India TMA have reported less than the risk-free return of 7.527 percent during the period under study. The mean return of other two funds viz. Principal Personal Tax Saver Fund, and Kotak Equity Arbitrage Growth have been marginally higher than the risk-free return. This marginal difference between mean risk-free return \& mean fund return and also negative excess return is a reflection of poor performance of these funds. However, 31 or 77.5 percent of sample funds have been found to have delivered superior performance when compared with the risk-free return by delivering excess return ranging between 4.768 percent to 26.841 percent. It also becomes clear from the table that the excess return of most of these funds have been either sufficient or significant. As such on the basis of excess return it can be concluded that overwhelming majority of sample funds have delivered superior performance during the reference period.

Excess return is not a true indicator of fund performance. It only reveals the risk premium being provided to the investors for taking systematic risk. Whether the risk premium provided is commensurate with the risk to which the fund investors are exposed is the question which can be answered by comparing the mean fund return with the mean market return in conjunction with their respective standard deviations. It is in view of this fact we have calculated funds abnormal excess returns which is the difference between mean daily annual fund return and the daily annual mean market return $\left(\mathrm{R}_{\mathrm{pt}}-\mathrm{R}_{\mathrm{mt}}\right)$. Positive abnormal excess return is an indication of better performance of funds or more than the average performance. Perusal of data about abnormal mean excess returns presented in Table 4.1 reveals that during the period under study, the sample schemes have reported a mean return of 18.393 percent which is higher than the mean market return of 10.037 percent which in overall terms reflects better performance of sample fund schemes. However, scheme-wise 32 sample funds accounting for 80 percent of the sample size have reported positive abnormal excess returns i.e. higher than the mean market return of 10.037 percent. While as 8 sample funds namely HSBC Cash Fund, JM Balanced Fund-(D), Kotak Equity Arbitrage Growth, Principal Personal Tax Saver Fund, Quantum Liquid Fund-Growth, Sahara Growth Fund-Div, SBI Arbitrage Opportunities Fund, and Templeton India TMA representing 20 percent of the sample size have reported negative abnormal excess returns ranging between 1.287 percent to 10.414 percent. Based on these results it can be safely concluded that the majority of the funds have delivered positive abnormal excess returns ranging between 2.259 percent to 24.331 percent.

Concluding about the performance of sample funds simply on the basis of abnormal excess returns again would be unsound for the reason that the returns are closely associated with the risk. Therefore, it is believed that the return of a fund would be influenced by its riskiness. Funds differ in riskiness whereas the market has an average risk whose Beta as such is taken equal to one. As such to draw meaningful conclusions about the performance of funds in comparison with the market return, the need is to either compare the risk adjusted fund return with the market return or look into the standard deviations of the sample funds and of the market. Perusal of data contained in Table 4.2 reveals that the mean standard deviation of all sample schemes during the period under study has been less than the mean standard deviation of the market portfolio. It can be seen from the said table that the mean standard deviation of all the sample schemes was 0.01419 compared to the mean standard deviation of 0.02016 for the market portfolio. Thus indicative of the fact that the investors of the sample schemes were made to assume less than market-risk i.e. the average risk.

Scheme- wise analysis shows that the standard deviation of all the sample schemes except one scheme namely Sahara Growth Fund-Dividend has been found less than the standard deviation of the market portfolio. The Sahara Growth Fund-Dividend has been found to have assumed greater than the market risk. This is the only scheme from sample funds which has reported negative return of -0.0377 percent. The standard deviation of the sample schemes has varied in the range between 0.00016 to 0.03543 . The significant difference in the standard deviation of sample schemes reflects the differences in the riskiness of different sample schemes. The other fact that is evident from the standard deviation of sample schemes is that out of six sample schemes whose returns are even less than the risk-free return, the standard deviation of five schemes namely HSBC Cash Fund, Quantum Liquid FundGrowth, SBI Arbitrage Opportunities Fund, Templeton India TMA, and Kotak Equity Arbitrage Growth have been found significantly less than the standard deviation of market portfolio. As such it can be inferred that perhaps the fund managers of these schemes have remained conservative in their approach while taking risk, which in turn seems cost some return to the investors of these funds. Contrary to it, the negative return on Sahara Growth FundDividend which has the highest standard deviation of 0.03543 of all the schemes and which is significantly higher than the standard deviation of marker portfolio, is indicative of the fact that the fund manager of the said schemes 
has been aggressive in taking risk thus exposing it's investors to more risk of loss. These findings reinforce the fact that lesser, the risk lesser the return and if excess risk is taken beyond the accepted level, there is a likelihood of more loss of return. It also becomes clear from the above discussion that if the risk is kept within the tolerable limits, there are greater chances of earning a normal return.

Table-1.2. Total Risk and Systematic Risk of Sample Funds

\begin{tabular}{|c|c|c|c|}
\hline Schemes & Portfolio Beta $(\beta)$ & $\begin{array}{l}\text { Portfolio SD } \\
(\sigma p)\end{array}$ & $\begin{array}{l}\text { Market SD } \\
(\sigma \mathrm{m})\end{array}$ \\
\hline Baroda Pioneer ELSS & -0.4926 & 0.0165 & 0.0202 \\
\hline Baroda Pioneer Growth & -0.5150 & 0.0172 & 0.0202 \\
\hline Birla Sun Life Frontline Equity & -0.4870 & 0.0162 & 0.0202 \\
\hline Birla Sun Life Top 100 Fund - Growth & -0.4736 & 0.0158 & 0.0202 \\
\hline Fidelity Equity Fund & -0.4505 & 0.0145 & 0.0202 \\
\hline Franklin India Bluechip Fund & -0.4725 & 0.0153 & 0.0202 \\
\hline HDFC Equity Fund & -0.4906 & 0.0156 & 0.0202 \\
\hline HDFC Tax Saver Fund & -0.4573 & 0.0141 & 0.0202 \\
\hline HSBC Cash Fund & 0.0008 & 0.0003 & 0.0202 \\
\hline HSBC Equity Fund & -0.4469 & 0.0147 & 0.0202 \\
\hline ICICI Pru Tax Plan & -0.4171 & 0.0142 & 0.0202 \\
\hline ICICI Prudential Discovery Fund -G & -0.3951 & 0.0142 & 0.0202 \\
\hline ING Balanced Fund (D) & -0.3608 & 0.0119 & 0.0202 \\
\hline ING Core Equity Fund -Growth & -0.5020 & 0.0162 & 0.0202 \\
\hline ING Tax Savings Fund & -0.4542 & 0.0162 & 0.0202 \\
\hline JM Balanced Fund - (D) & -0.3946 & 0.0139 & 0.0202 \\
\hline Kotak 50 Growth & -0.5166 & 0.0154 & 0.0202 \\
\hline Kotak Equity Arbitrage Growth & 0.0112 & 0.0012 & 0.0202 \\
\hline L\&T Growth Fund & -0.5396 & 0.0177 & 0.0202 \\
\hline LIC Nomura Mf Equity Fund & -0.5422 & 0.0183 & 0.0202 \\
\hline LIC Nomura Mf India Vision Fund (D) & -0.4979 & 0.0174 & 0.0202 \\
\hline Morgan Stanley Growth Fund & -0.4854 & 0.0164 & 0.0202 \\
\hline Principal Index Fund & -0.5536 & 0.0180 & 0.0202 \\
\hline Principal Personal Tax Saver Fund & -0.4938 & 0.0181 & 0.0202 \\
\hline Quantum Liquid Fund - Growth & 0.0004 & 0.0002 & 0.0202 \\
\hline Quantum Long-Term Equity Fund & -0.4549 & 0.0144 & 0.0202 \\
\hline Reliance Growth Fund & -0.4401 & 0.0152 & 0.0202 \\
\hline Reliance Regular Savings Fund & -0.3570 & 0.0122 & 0.0202 \\
\hline Sahara Growth Fund & -0.4756 & 0.0187 & 0.0202 \\
\hline Sahara Growth Fund - Div & -0.4270 & 0.0354 & 0.0202 \\
\hline SBI Arbitrage Opportunities Fund & 0.0123 & 0.0011 & 0.0202 \\
\hline SBI Magnum NRI Investment Fund- (D) & -0.4296 & 0.0134 & 0.0202 \\
\hline SBI One India Fund & -0.4929 & 0.0149 & 0.0202 \\
\hline Sundaram Growth Fund & -0.5309 & 0.0175 & 0.0202 \\
\hline Sundaram Select Focus & -0.5166 & 0.0173 & 0.0202 \\
\hline Tata Pure Equity Fund & -0.4633 & 0.0154 & 0.0202 \\
\hline Tata Tax Advantage Fund & -0.4112 & 0.0140 & 0.0202 \\
\hline Templeton India TMA & 0.0003 & 0.0002 & 0.0202 \\
\hline UTI - Growth Retail & -0.3988 & 0.0135 & 0.0202 \\
\hline UTI - Opportunities Fund & -0.2045 & 0.0154 & 0.0202 \\
\hline
\end{tabular}

Note:

- $\boldsymbol{\beta}$ : Portfolio Beta

- $\sigma p$ : Standard Deviation Portfolio

• $\boldsymbol{\sigma m}$ : Standard Deviation Market

Source: AMC reports, NSE historical data and RBI reports

From the above discussion it can be safely concluded that on the whole the sample schemes during the period under reference have delivered higher returns than the market at a risk which was even less than the risk of market portfolio. Scheme-wise overwhelming majority of sample schemes i.e. 80 percent sample size have been found to have outperformed the market portfolio across all the performance measures viz. excess return, abnormal excess return and risk-adjusted return. Some small percentages of funds have also been found to have underperformed the market portfolio.

Mutual funds work on the basis of two maximums i.e. maximization returns and diversification of risk. To achieve these twin objectives, the fund managers are required to evolve efficient investment management practices which calls for a strategic allocation of the funds money to broad asset categories, to identify and select undervalued stocks for the portfolio and timing market movements (Market Timing skills). Therefore, the good or poor performance of the fund managers can be attributed either to the stock selection skills or to the market timing abilities of the fund managers. Owing to this fact, the performance of sample schemes as indicated above has been decomposed into two parts viz. the performance attributable to the stock selection ability and the market timing skills of the fund managers of schemes respectively. The detailed analysis of the stock selection skills and market timing abilities of fund managers of the sample schemes during the period under study has been made in paras that follows this discussion. 
Table-1.3. Sharpe Ratio and Tyrenor Ratio of Sample Funds

\begin{tabular}{|c|c|c|c|c|c|}
\hline Schemes & $\begin{array}{l}\text { Excess Return } \\
\text { (Rpt - Rft) }\end{array}$ & $\begin{array}{l}\text { Portfolio } \\
\text { SD ( } \sigma p) \\
\end{array}$ & $\begin{array}{l}\text { Sharpe } \\
\text { Ratio }\end{array}$ & $\begin{array}{l}\text { Portfolio } \\
\text { Beta }(\boldsymbol{\beta}) \\
\end{array}$ & $\begin{array}{l}\text { Tyrenor } \\
\text { Ratio }\end{array}$ \\
\hline Baroda Pioneer ELSS & 0.1006 & 0.0165 & 6.0970 & -0.49261 & -0.20422 \\
\hline Baroda Pioneer Growth & 0.1588 & 0.0172 & 9.2326 & -0.51501 & -0.30834 \\
\hline Birla Sun Life Frontline Equity & 0.1648 & 0.0162 & 10.1728 & -0.48695 & -0.33843 \\
\hline Birla Sun Life Top 100 Fund - Growth & 0.1242 & 0.0158 & 7.8608 & -0.47362 & -0.26224 \\
\hline Fidelity Equity Fund & 0.1372 & 0.0145 & 9.4621 & -0.45048 & -0.30456 \\
\hline Franklin India Bluechip Fund & 0.1714 & 0.0153 & 11.2026 & -0.47255 & -0.36271 \\
\hline HDFC Equity Fund & 0.2235 & 0.0156 & 14.3269 & -0.49064 & -0.45553 \\
\hline HDFC Tax Saver Fund & 0.1833 & 0.0141 & 13.0000 & -0.4573 & -0.40083 \\
\hline HSBC Cash Fund & -0.0131 & 0.0003 & -43.6667 & 0.0008 & -16.375 \\
\hline HSBC Equity Fund & 0.1023 & 0.0147 & 6.9592 & -0.44685 & -0.22894 \\
\hline ICICI Pru Tax Plan & 0.1997 & 0.0142 & 14.0634 & -0.41706 & -0.47883 \\
\hline ICICI Prudential Discovery Fund - Growth & 0.2684 & 0.0142 & 18.9014 & -0.39511 & -0.6793 \\
\hline ING Balanced Fund (D) & 0.0787 & 0.0119 & 6.6134 & -0.36079 & -0.21813 \\
\hline ING Core Equity Fund -Growth & 0.1043 & 0.0162 & 6.4383 & -0.502 & -0.20777 \\
\hline ING Tax Savings Fund & 0.0996 & 0.0162 & 6.1481 & -0.4542 & -0.21929 \\
\hline JM Balanced Fund - (D) & -0.0201 & 0.0139 & -1.4460 & -0.39465 & 0.050931 \\
\hline Kotak 50 Growth & 0.1057 & 0.0154 & 6.8636 & -0.51663 & -0.2046 \\
\hline Kotak Equity Arbitrage Growth & 0.0019 & 0.0012 & 1.5833 & 0.00001 & 190 \\
\hline L\&T Growth Fund & 0.1155 & 0.0177 & 6.5254 & -0.53963 & -0.21404 \\
\hline LIC Nomura Mf Equity Fund & 0.0678 & 0.0183 & 3.7049 & -0.54219 & -0.12505 \\
\hline LIC Nomura Mf India Vision Fund (D) & 0.0477 & 0.0174 & 2.7414 & -0.49786 & -0.09581 \\
\hline Morgan Stanley Growth Fund & 0.1028 & 0.0164 & 6.2683 & -0.48543 & -0.21177 \\
\hline Principal Index Fund & 0.1149 & 0.018 & 6.3833 & -0.55356 & -0.20757 \\
\hline Principal Personal Tax Saver Fund & 0.0122 & 0.0181 & 0.6740 & -0.00027 & -45.1852 \\
\hline Quantum Liquid Fund - Growth & -0.0011 & 0.0002 & -5.5000 & 0.00039 & -2.82051 \\
\hline Quantum Long-Term Equity Fund & 0.1524 & 0.0144 & 10.5833 & -0.4549 & -0.33502 \\
\hline Reliance Growth Fund & 0.2132 & 0.0152 & 14.0263 & -0.44011 & -0.48442 \\
\hline Reliance Regular Savings Fund & 0.1956 & 0.0122 & 16.0328 & -0.35704 & -0.54784 \\
\hline Sahara Growth Fund & 0.1113 & 0.0187 & 5.9519 & -0.47562 & -0.23401 \\
\hline Sahara Growth Fund - Div & -0.079 & 0.0354 & -2.2316 & -0.427 & 0.185012 \\
\hline SBI Arbitrage Opportunities Fund & -0.0002 & 0.0011 & -0.1818 & 0.01229 & -0.01627 \\
\hline $\begin{array}{l}\text { SBI Magnum NRI Investment Fund-Flexi Asset } \\
\text { (D) Balanced }\end{array}$ & 0.0737 & 0.0134 & 5.5000 & -0.42955 & -0.17157 \\
\hline SBI One India Fund & 0.0308 & 0.0149 & 2.0671 & -0.49286 & -0.06249 \\
\hline Sundaram Growth Fund & 0.1474 & 0.0175 & 8.4229 & -0.53085 & -0.27767 \\
\hline Sundaram Select Focus & 0.14 & 0.0173 & 8.0925 & -0.51664 & -0.27098 \\
\hline Tata Pure Equity Fund & 0.1614 & 0.0154 & 10.4805 & -0.46333 & -0.34835 \\
\hline Tata Tax Advantage Fund & 0.1686 & 0.014 & 12.0429 & -0.41117 & -0.41005 \\
\hline Templeton India TMA & -0.0034 & 0.0002 & -17.000 & 0.00034 & -10 \\
\hline UTI - Growth Retail & 0.1303 & 0.0135 & 9.6519 & -0.39876 & -0.32676 \\
\hline UTI - Opportunities Fund & 0.2534 & 0.0154 & 16.4545 & -0.2045 & -1.23912 \\
\hline
\end{tabular}

Note:

- Rpt: Mean Daily Annual Fund Return

- Rft : Risk Free Return

- $\quad$ op: Standard Deviation Portfolio

- $\quad \beta$ : Portfolio Beta

Source: AMC reports, NSE historical data and RBI reports

To comment on the performance of sample schemes in comparison with the market portfolio after taking into account the differences in the risk-ness of the schemes. We have also calculated Sharpe ratio \& Treynor ratio, the details of which have been presented in Table 1.3. These two ratios measure the unit of reward per unit of risk. The difference between the two ratios is that the Sharpe ratio takes into account total risk (Systematic \& Unsystematic risk) whereas Treynor ratio considers systematic risk only. Perusal of data presented in Table 1.3 reveals that the Sharpe ratio for the market is 1.265 .

\section{Conclusion}

The mutual fund industry in Indian has witnessed enough growth on many parameters be it number of fund houses, number of schemes, funds mobilized, assets under management etc. The mutual fund industry in the beginning consisted of UTI mutual fund only, but today the industry consists of all the three sectors viz. public sector, private sector and foreign fund houses. The fund houses which were just 31 in number 1997-98, have grown to 44 funds as on 2013.

Similarly, the number of schemes in operation has grown from 235 in 1997-98 to 1,131 schemes at a compound growth rate of 14 percent. The major schemes in operation are regular Income Schemes which account for 52 percent of the total schemes, followed by growth schemes with 29 percent of the total schemes. ELSS is the only scheme which has recorded negative growth during the period.

The total funds raised by the industry in the country has increased from INR 18,701 crores in 1997-98 to INR $88,59,515$ crores in 2010-11 at a compound growth rate of 67 percent. The public sector mutual funds were major mobilizer of funds up to 1998-99. With around 66 percent share, but 1999 onwards, private sector mutual funds dominated the industry in terms of funds mobilized with a share of 90.59 percent as on 2003-04. 
The MMMFs emerged as a major contributor to the funds mobilized and since 2000-01 it continues to dominate the industry in terms of funds mobilized. Contrary the income scheme which was initially the major contributor has gradually lost its ground to the MMMFs.

In terms of AUM, the industry recorded significant growth. The net assets under the management have increased from INR 68,984 crores in 1997-98 to INR 5,92,250 crores in 2010-11 at a compound rate of 20 percent. Category-wise, the private sector funds have recorded a compound growth rate of 48 percent as against the growth rate of 6 percent by the public sector funds, indicating thereby that the dominating place of private sector funds which at one point of time accounted for only 5.93 percent of AUMs which as on 2010-11 account for 77.9 percent. One things that is evident, is that the in terms of AUMs, mutual fund industry has recorded more than satisfactory growth since its inception, however, the growth is more pronounced towards the private sector funds and the public sector funds which dominated the fund industry in the country, have been overtaken by the public sector funds.

Product wise Indian fund industry is broadly consisted of six product categories viz. liquid and money market, equity oriented, debt oriented, balanced, gilt and gold ETFs. The industry is dominated by gilt and liquid money market and these product categories account for around 73 percent of AUMs in 2013. The equity oriented funds account for only 1 percent of the total AUMs as on 2013. Besides, the gold ETFs have recorded significant growth during the last few years from a much smaller base.

While looking at AUM composition by investor segment, corporate investments constitute nearly half of the AUMs, followed by high net worth investors.

The retail segment account for just 20 percent of AUMs. As such, it can be inferred that the mutual funds have failed to penetrate deep into the retail segment. Retail investors in the country continue to prefer bank deposits and the real estate sector. The poor participation of the retail segment through mutual funds is reported due to very low levels of awareness in financial literacy, show capital market growth and the cultural and behavioral factors. The other important factor is the failure of the mutual fund industry to reach out to the nook and corner of the country. The top five cities namely, Mumbai, Delhi, Chennai, Bangalore and Kolkata contribute 74 percent of the total funds mobilized.

Therefore, among other things, the need is to increase the penetration ratio.

One of the important goals of the mutual fund industry is to attract and mobilize major portion of the House Hold Savings in order to enable the small savers to benefit from the economic growth by facilitating them to part their savings into the assets which yield better their risk-adjusted returns.

Therefore, the question arises, has the Indian mutual industry succeeded in achieving this goal. The fact about it is that the Gross Domestic Saving (GDS) as a percentage of GDP has recorded significant growth and the HHS account for three quarter of the GDS.

Although the mutual fund industry has succeeded in increasing its share from the GDS but the ratio of AUM to GDP is much lower than the developed countries of the world. Further, the house hold sector which account for major position of the gross domestic savings have shown least preference for mutual funds, rather these have been find to prefer most deposits, both banking and non-banking.

Though the mutual fund industry has recorded significant progress on all fronts yet it has not be able to utilize its potential fully.

On almost on all parameters it is far behind the developed economics and even most of the emerging economics of the world. The industry is confronted with number of challenges like low penetration ratio, lack of product differentiation, lack of investor awareness and ability to communicate value to customers, lack of interest of retail investors towards mutual funds and evolving nature of the industry. Therefore, if the industry has to utilize its potential fully, it has to address these challenges.

To address these challenges the need is to penetrate into the tier II \& tier III cities which among other things would require to seek more awareness of the investors through strategic initiatives and investor education drives. Apart from this, the mutual fund industry has to continually deliver superior risk-adjusted returns to the investors. This would require the fund managers on the one hand to exhibit superior stock selectivity and market timing performance consistently and in the other hand to keep the fund costs under check. Delivering superior riskadjusted returns consistently will automatically create a niche for the mutual funds.

\section{References}

Amihud, Y. and R. Goyenko, 2013. Mutual fund's R2 as predictor of performance. Review of Financial Studies, 26(3): 667-694.

Bali, T.G., S.J. Brown and M.O. Caglayan, 2014. Macroeconomic risk and hedge fund returns. Journal of Financial Economics, 114(1): 1-19. Carhart, M.M., 1997. On persistence in mutual fund performance. Journal of Finance, 52(1): 57-82.

Choi, N., M. Fedenia, H. Skiba and T. Sokolyk, 2017. Portfolio concentration and performance of institutional investors worldwide. Journal of Financial Economics, 123(1): 189-208.

Cortez, M.D.C. and F. Silva, 2002. Conditioning information on portfolio performance evaluation: A reexamination of performance persistence in the Portuguese mutual fund market. Finance India, 16(4): 1393.

Fama, E.F., 1972. Components of investment performance. Journal of Finance, 27(3): 551-567.

Fortin, R. and S. Michelson, 1995. Are load mutual funds worth the price? Journal of Investing, 4(1): 89-94.

Grinblatt, M., G. Jostova, L. Petrasek and A. Philipov, 2016. Style and skill: Hedge funds, mutual funds and momentum. Working Paper, 3: 26.

Ippolito, R.A., 1989. Efficiency with costly information: A study of mutual fund performance, 1965-1984. Quarterly Journal of Economics, 104(1): 1-23.

Irwin, F., B. Marshall and C. Jean, 1970. Mutual funds and other institutional investors; a new perspective. New York: McGraw Hill Book Company.

Jagric, T., B. Podobnik, S. Strasek and V. Jagric, 2015. Risk-adjusted performance of mutual funds: Some tests. South-Eastern Europe Journal of Economics, 5(2).

Jensen, M.C., 1968. The performance of mutual funds in the period 1945-1964. Journal of Finance, 23(2): 389-416.

Jiang, H. and Z. Sun, 2014. Dispersion in beliefs among active mutual funds and the cross-section of stock returns. Journal of Financial Economics, 114(2): 341-365.

Khare, S.K., 2007. Mutual funds: A refuge for small investors. Southern Economist, 45(18).

Kholkin, K. and E. Haug, 2016. Analyzing risk and returns of Norwegian equity mutual funds (Master's Thesis, Nord Universitet).

Klemkosky, R.C., 1973. The bias in composite performance measures. Journal of Financial and Quantitative Analysis, 8(03): 505-514. 
Rohleder, M., D. Schulte and M. Wilkens, 2014. Management of flow risk in mutual funds. Review of Quantitative Finance and Accounting, 48(1): 31-56.

Sharpe, W.F., 1966. Mutual fund performance. Journal of Business, 39(1): 119-138.

Soni, R., 2017. Designing a portfolio based on risk and return of various asset classes. International Journal of Economics and Finance, 9(2): 142.

Treynor, J.L., 1965. How to rate management of investment funds. Harvard Business Review, 43(1): 63-75.

Citation | Bilal Ahmad Pandow; Khurshid Ahmad Butt (2017). Risk and Return Analysis of Mutual Fund Industry in India. Journal of Banking and Financial Dynamics, 1: 54-65.

Licensed: This work is licensed under a Creative Commons Attribution 3.0 License (c)) Er

Publisher: Eastern Centre of Science and Education

Contribution/Acknowledgement: Both authors contributed to the contribution/Acknowledgement:
concen and design of the study.
Funding: This study received no specific financial support.

Competing Interests: The authors declare that they have no conflict of interests.

Transparency: The authors confirm that the manuscript is an honest, accurate, and transparent account of the study was reported; that no vital features of the study have been omitted; and that any discrepancies from the study as planned have been explained.

Ethical: This study follows all ethical practices during writing.

Eastern Centre of Science and Education is not responsible or answerable for any loss, damage or liability, etc. caused in relation to/arising out of the use of the content. Any queries should be directed to the corresponding author of the article. 